\title{
PROSPECTIVE EVALUATION OF PERIARTICULAR HYALURONIC ACID INFILTRATION FOR THE TREATMENT OF LATERAL EPICONDYLITIS
}

\author{
AVALIAC̦ÃO PROSPECTIVA DA INFILTRAC̦ÃO \\ PERIARTICULAR DE ÁCIDO HIALURÔNICO PARA \\ O TRATAMENTO DA EPICONDILITE LATERAL
}

\author{
Guilherme augusto Stirma ${ }^{1}$ (i), Deginaldo Holanda Chaves $^{1}$ (i), Simone Tortato ${ }^{1}$ (i), Paulo Santoro Belangero ${ }^{1}$ (i), \\ Paulo Henrique SCHMidT Lara ${ }^{1}$ (1), BenNo EJNISMan ${ }^{1}$ (i)
}

1. Universidade Federal de São Paulo, Paulista School of Medicine, São Paulo, SP, Brazil.

\section{ABSTRACT}

Objective: To prospectively, clinically and functionally follow-up patients previously diagnosed with lateral epicondylitis after periarticular application of hyaluronic acid and analyze the results. Methods: All patients were previously treated conservatively and had no clinical improvement. Data such as age, positivity for specific tests (Cozen and Mill), visual analogue pain scale (VAS) before and during dorsiflexion of the wrist with resistance, diagnosis time, Mayo Elbow Performance Score was collected. Patients were reevaluated 30 and 90 days after application. Results: The positivity rates for Cozen and Mill tests were identical, starting at $100 \%$, dropping to $50 \%$ after one month, and ending at $41.7 \%$ after 3 months. The initial Mayo Elbow Score average was 61.3 points; 85.8 in the first month, remaining at 85 in the third month. VAS in active force situations had the initial average of 8.1; after one month it dropped to 3.8, and 3.6 after three months. At rest, the initial average was 5.9; after one month it decreased to 3 and ended at 2.1 in three months. Conclusion: Patients showed improvement in pain parameters, in the Mayo Elbow Performance Score standard, but with $25 \%$ of failure in satisfaction. Level of evidence IV, Case series.

Keywords: Hyaluronic Acid. Tennis Elbow. Mayo Elbow Performance Score.
RESUMO

Objetivo: Acompanhar de maneira prospectiva, clínica e funcionalmente, os pacientes previamente diagnosticados com epicondilite lateral após a aplicação periarticular de ácido hiaIurônico e analisar os resultados. Métodos: Todos pacientes foram tratados previamente de maneira conservadora e não obtiveram melhora clínica. Foram coletados idade, positividade nos testes especificos (Cozen e Mill), escala visual analógica da dor (EVA) antes e durante a dorsoflexão contrarresistência do punho, tempo de diagnóstico, Mayo Elbow Performance Score. Os pacientes foram reavaliados após 30 e 90 dias das aplicações. Resultados: Os índices de positividade para os testes de Cozen e Milll foram idênticos, começaram em $100 \%$, caíram para $50 \%$ após 1 mês, e terminaram em 41,7\% em 3 meses. A média inicial do Mayo Elbow Score foi 61,3 pontos; 85, 8 no primeiro mês e manteve-se em 85 no terceiro mês. A EVA em situações de força ativa teve a média inicial de 8,1; após 1 mês caiu para 3,8, e 3,6 em 3 meses. Em repouso, a média inicial foi 5,9; após 1 mês diminui para 3, e terminou com 2,1 em 3 meses. Conclusão: Os pacientes apresentaram melhora nos parâmetros de dor, no padrão Mayo Elbow Performance Score, mas com 25\% de falha na satisfação. Nível de evidência IV, Série de casos.

Descritores: Ácido Hialurônico. Epicondilite Lateral. Mayo Elbow Performance Score

Citation: Stirma GA, Chaves DH, Tortato S, Belangero PS, Lara PHS, Ejnisman B. Prospective evaluation of periarticular hyaluronic acid infiltration for the treatment of lateral epicondylitis. Acta Ortop Bras. [online]. 2020;28(3):107-10. Available from URL: http://www.scielo.br/aob.

\section{INTRODUCTION}

Lateral epicondylitis is one of the main causes of pain and functional incapacity of the elbow, affecting $1 \%$ to $3 \%$ of the adult population annually. ${ }^{1}$ Despite the classic relationship to the practice of tennis (tennis elbow), only $5 \%$ to $10 \%$ of total cases of this disease affect practitioners of this sport. ${ }^{2}$

All authors declare no potential conflict of interest related to this article.

The study was conducted at the Universidade Federal de São Paulo (UNIFESP), Department of Orthopedics and Traumatology, Sports Traumatology Center (CETE).

Correspondence: Guilherme Augusto Stirma. Rua Arruda Alvim, 297, apartment 205, São Paulo, SP, Brazil, 05410020. drstirma@outlook.com 
Although the terms epicondylitis and tendinitis are both descriptive of the "tennis elbow" condition, and that the existence of inflammatory process in the early stages is recognized, histopathological studies characterize it not only as an inflammatory condition, but also as a fibroblastic and vascular response, known as angiofibroblastic degeneration. The tissue changes are characterized by microruptures of collagen fibers, accompanied by the invasion of fibroblasts, creation of abnormal vascular tissue and granulation tissue (although the cicatricial tissue created is grayish, friable and susceptible to new lesions). ${ }^{1,3,4}$

The pharmacological and non-pharmacological treatments are the recommended methods for this condition; however, there is no consensus or specific protocols for the conservative treatment of lateral epicondylitis. ${ }^{1}$

The application of periarticular hyaluronic acid $(\mathrm{HA})$ is an alternative with clinical effects that have been positive for lateral epicondylitis and periarticular disorders. Testing in models in vitro has suggested that HA might increase tenocyte viability, as well as production and deposition of type I collagen. Its viscoelastic properties reduce surface friction in the tendons, increasing sliding. Thus, it provides pain reduction, decreased joint stiffness, patient satisfaction as well as the recently-confirmed clinical safety of the application in torsional ligament lesions in the ankle..$^{5-10}$

Due to the lack of prospective analyses on the application of periarticular hyaluronic acid on the treatment of lateral epicondylitis, the failure of non-surgical treatments associated with its collateral effects may be due to the absence of protocols for the conservative treatment. The objective of this study is to follow patients previously diagnosed with lateral epicondylitis in a prospective, clinically pragmatic fashion, after the periarticular application of hyaluronic acid, with following result analysis after the treatment.

\section{METHODS}

Study approved by the ethics and research committee of the institution under the number 04798918.0.0000.5505 with opinion $3,318,006$. All 52 patients diagnosed with lateral epicondylitis for one year (2018) were analyzed and all those previously subjected to the conservative treatment (physiotherapy with a minimum of three months, in conjunction or not with corticosteroid infiltration and oral analgesia) who did not obtain clinical improvement. The patients signed the free and informed consent form before participation. Data on age, laterality and test-positivity (Cozen and Mill, for the specific case of lateral epicondylitis) was collected, as well as results on the visual analog pain scale (VAS) before and during wrist dorsiflexion with resistance scoring from 0 to 10 , in which 0 was absence of pain and 10 was unbearable pain. In addition, the following variables were analyzed: diagnosis time, Mayo Elbow Performance Score and time since the previously conservative treatment within an accepted minimum of three months.

The Mayo Elbow Performance Score (MEPS) is a performance index widely used to evaluate clinical outcomes for a variety of elbow-related conditions. It consists in the evaluation of pain, motion arc, stability and patient-stablished classification of daily function. Pain is classified into four variables. The score ranges from 0 to 100 with higher values indicating better result.1

The diagnosis of lateral epicondylitis was confirmed via ultrasound in conjunction with clinical examination. Both the Cozen and the Mill tests were performed, and the possibility of differential diagnoses such as plica syndrome, radial nerve compression, and posterolateral instability was rejected. Radiographic imaging was performed to exclude fractures.
Infiltrations of periarticular hyaluronic acid were ultrasound-guided, with directions in the lateral epicondyle and the extensor carpi radialis brevis. The procedures were performed by a radiologist specialized in the musculoskeletal system and by an orthopedist specialized in shoulders and elbows. Two doses within an interval of one week were applied. The applied dose of sodium hyaluronate was $12 \mathrm{mg} / 1.2 \mathrm{~mL}$ according to the manufacturer's guidance. The medication was donated by the manufacturer (Sportvis ${ }^{\mathrm{TM}}$ Injectable $12 \mathrm{mg} / 1.2 \mathrm{~mL}$ with 1 filled syringe).

Patients were reevaluated after 30 and 90 days since the applications. Data from the specific tests for lateral epicondylitis (Cozen and Mill) were collected, as well as results from the visual analog pain scale (VAS) before and during wrist dorsiflexion, the Mayo Elbow Performance Score and patient satisfaction after each treatment.

All cases with fracture sequelae were excluded, as well as cases of patients regularly receiving corticosteroids for any medical reason, cervical radiculopathy and peripheral nerve diseases.

There is no conflict of interest with the applied medication.

\section{Infiltration technique}

The performed technique consists in local antisepsis with chlorhexidine or topical iodine. A $27 \mathrm{~mm}$ gauge needle is directed to the lateral epicondyle with the elbow flexed at $90^{\circ}$ (Figure 1). The medication is injected through the "fan" technique with up to $1 \mathrm{~cm}$ in radius. After application, five active movements of flexion/ extension of the elbow and pronation/supination of the forearm are performed, and the patient is instructed to avoid physical activities or repetitive work with the upper limb in question for 24 hours.

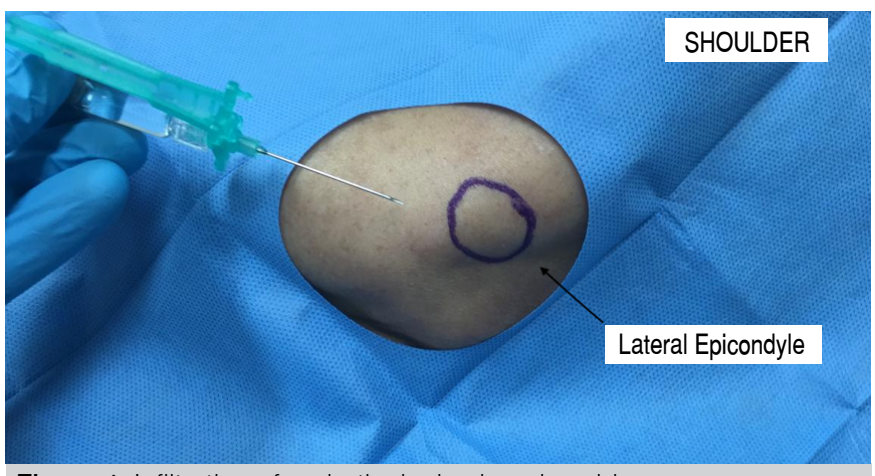

Figure 1. Infiltration of periarticular hyaluronic acid.

After application, the patients were instructed to use simple analgesic medications (dipyrone and acetaminophen), in conjunction to rehabilitation exercises (standard home procedures of stretching and strengthening $)^{12}$ guided by a physical therapist of the institution and application of cold compresses at the site according to necessity.

\section{RESULTS}

Twelve patients met the inclusion criteria and were subject to the local infiltrations. Eight, 75\%, were women and four, 25\%, were men. In eight cases (75\%) laterality was on the right and in four cases (25\%) on the left. The mean age was $51.4 \pm 6.2$ years and mean diagnosis time was $8.4 \pm 3.1$ months.

Previous treatment involved physical therapy and analgesia in $66.7 \%$ of cases. Four patients (25\%) were previously subjected to corticoid 
infiltration and at least one, $8.3 \%$, to acupuncture. The Cozen and Mill tests were positive in all patients after the first evaluation. After application of the medication, the positivity rates for both tests were identical; started at $100 \%$ (all 12 patients), dropped to $50 \%$ (six patients) after one month and ended at $41.7 \%$ (four patients) in three months (Tables 1 and 2, Figure 2).

Table 1. Compares moments for the Cozen test distribution.

\begin{tabular}{c|c|c|c|c|c|c}
\hline \multirow{2}{*}{ Cozen Test } & \multicolumn{2}{|c|}{ Initial } & \multicolumn{2}{c|}{ 1 month } & \multicolumn{2}{c}{ 3 months } \\
\cline { 2 - 7 } & $\mathrm{N}$ & $\%$ & $\mathrm{~N}$ & $\%$ & $\mathrm{~N}$ & $\%$ \\
\hline Negative & 0 & $0 \%$ & 6 & $50 \%$ & 7 & $58.3 \%$ \\
\hline Positive & 12 & $100 \%$ & 6 & $50 \%$ & 5 & $41.7 \%$ \\
\hline
\end{tabular}

Table 2. Compares moments for the Mill test distribution.

\begin{tabular}{c|c|c|c|c|c|c}
\hline \multirow{2}{*}{ Mill Test } & \multicolumn{2}{|c|}{ Initial } & \multicolumn{2}{c|}{ 1 month } & \multicolumn{2}{c}{ 3 months } \\
\cline { 2 - 7 } & $\mathrm{N}$ & $\%$ & $\mathrm{~N}$ & $\%$ & $\mathrm{~N}$ & $\%$ \\
\hline Negative & 0 & $0 \%$ & 6 & $50 \%$ & 7 & $58.3 \%$ \\
\hline Positive & 12 & $100 \%$ & 6 & $50 \%$ & 5 & $41.6 \%$ \\
\hline
\end{tabular}

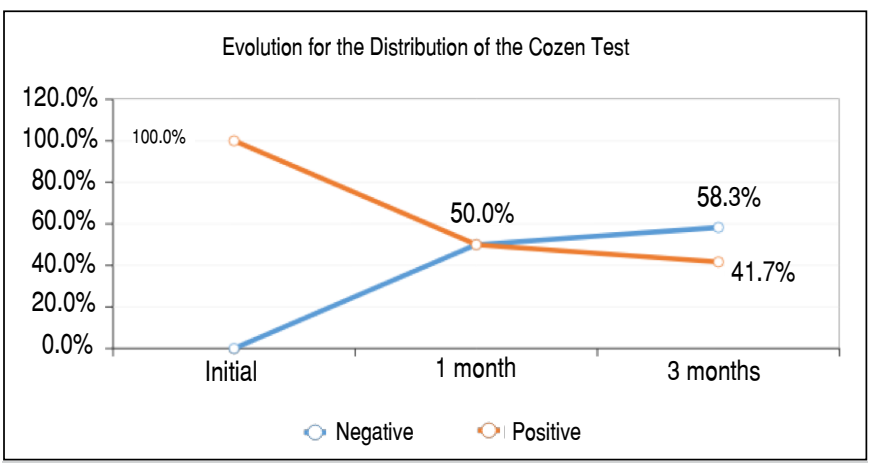

Figure 2. Evolution for the distribution of the Cozen test.
In relation to the application of the Mayo Elbow Score, the initial mean was 61.3 points, while in the first month after the infiltration of sodium hyaluronate it went up to 85.8 and kept still in 85 after the third month $(p=0.009$, Table 3$)$.

\begin{tabular}{|c|c|c|c|c|c|c|c|c|c|}
\hline $\begin{array}{l}\text { Mayo } \\
\text { Elbow }\end{array}$ & Mean & Median & $\begin{array}{l}\text { Standard } \\
\text { Deviation } \\
\end{array}$ & $\mathrm{CV}$ & Min & Max & $\mathbf{N}$ & $\mathrm{Cl}$ & $p$-value \\
\hline Initial & 61.3 & 55 & 15.5 & $25 \%$ & 35 & 85 & 12 & 8.8 & \multirow{3}{*}{0.009} \\
\hline 1 month & 85.8 & 85 & 15.5 & $18 \%$ & 55 & 100 & 12 & 8.8 & \\
\hline 3 months & 85 & 100 & 21.2 & $25 \%$ & 40 & 100 & 12 & 12 & \\
\hline
\end{tabular}

There was a significant reduction in both VAS scores analyzed. VAS in situations of active force (during wrist dorsiflexion with resistance) had an initial mean of 8.1 and after 1 month it went down to 3.8, ending with 3.6 in 3 months ( $p=0.005$, Figure 3 ). Resting VAS had a mean of 5.9 and after 1 month it decreased to 3 , ending at 2.1 in 3 months ( $p=0.015$, Table 4).

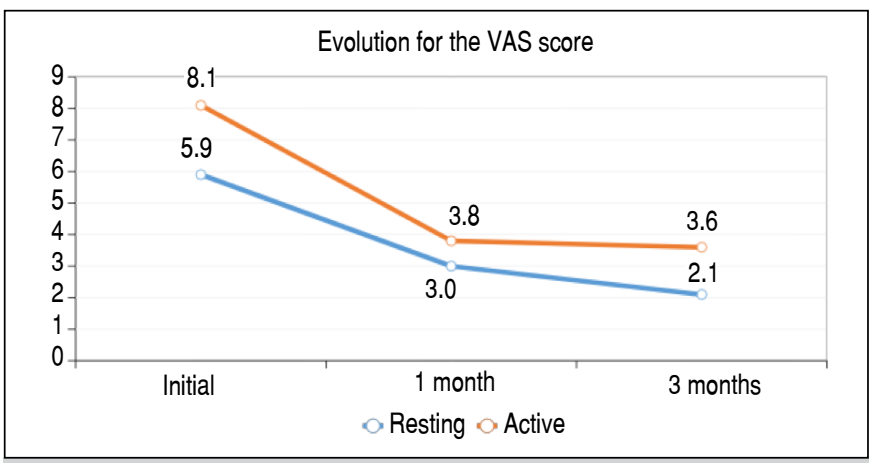

Figure 3. Evolution for the VAS score.

Table 4. Compares moments for VAS score.

\begin{tabular}{|c|c|c|c|c|c|c|c|c|c|c|}
\hline \multicolumn{2}{|c|}{ VAS } & Mean & Median & Standard Deviation & CV & Min & Max & $\mathbf{N}$ & $\mathrm{Cl}$ & p-value \\
\hline \multirow{3}{*}{ Resting } & Initial & 5.9 & 6 & 2.6 & $45 \%$ & 2 & 10 & 12 & 1.5 & \multirow{3}{*}{0.015} \\
\hline & 1 month & 3 & 2.5 & 2.9 & $96 \%$ & 0 & 7 & 12 & 1.6 & \\
\hline & 3 months & 2.1 & 0 & 3.3 & $156 \%$ & 0 & 9 & 12 & 1.8 & \\
\hline \multirow{3}{*}{ Active } & Initial & 8.1 & 8 & 1.6 & $20 \%$ & 5 & 10 & 12 & 0.9 & \multirow{3}{*}{0.005} \\
\hline & 1 month & 3.8 & 3.5 & 3.4 & $87 \%$ & 0 & 9 & 12 & 1.9 & \\
\hline & 3 months & 3.6 & 1 & 4 & $113 \%$ & 0 & 10 & 12 & 2.3 & \\
\hline
\end{tabular}

When questioned about satisfaction with the treatment conducted, $66.7 \%$ of patients (a total of 8 ) in a month were satisfied ( $p=0.102)$, and after three months 75\% (a total of 9 ) were satisfied ( $p=0.014$ ). There were no complications or adverse effects with the medications applied.

\section{DISCUSSION}

Our study presented the analysis of 12 patients, with previous clinical treatment showing resistance to pain improvement both in rest and in active movement, in one month $(p=0.005)$ up until three months ( $p=0.015)$, as well as initial increase in the Mayo Elbow Score index of 61.3 points to 85.8 points in the first month and 85 in the third month $(p=0.009)$ and high patient satisfaction after three months of treatment, in $75 \%$ of the cases ( $p=0.014)$. Petrella et al. ${ }^{5}$ examined 331 competitive tennis athletes (unlike our study, with lack of previous treatment) diagnosed with lateral epicondylitis through a randomized prospective clinical trial (165 AH $\times 166$ placebos). Two injections of $\mathrm{HA}$ within a seven-day interval were applied, and the results were compared with the placebo group that received saline solution during a 1-year follow-up. They concluded, like our patients, that the cases in which injections of HA were applied proceeded with significant improvement in pain, high satisfaction rate and earlier return to sporting activities in relation to the control group, even after 1-year follow-up. There was no description of serious adverse effects. Fogli et al. ${ }^{13}$ analyzed 28 patients with lateral epicondylitis for 56 days. After the application of the medication, they discovered through the use of ultrasound equipment a decrease in tendon thickness, reduction in local vascularization and improvement in the visual analog pain scale. Kumai et al. ${ }^{14}$ applied HA in only one dose for enthesopathies (plantar fasciitis, achilles tendinopathy and lateral 
epicondylitis) and studied the results after one week. In 16 cases, patients had elbow-related complaints and even with the short period after periarticular injections, improvement could already be visualized in the visual analog pain scale at $-2.55 \pm 2.43$.

A recently published meta-analysis compared the efficacy of several local application therapies for lateral epicondylitis. Dong et al. reported that hyaluronic acid injection may be more effective in the medium-term than other therapies like autologous blood injection, platelet-rich plasma, botulinum toxin and placebo. However, more studies and evidence are needed to prove its superiority. ${ }^{15}$

Hyaluronic acid (HA), also known as hyaluronan or hyaluronate, is a glycosaminoglycan composed of disaccharidic units of $\mathrm{N}$-acetyl-glucosamine and glucuronic acid. The average molecular weight of $\mathrm{HA}$ in the synovial fluid is 5 to $7 \times 10^{6} \mathrm{Da} .^{16}$ Hyaluronic acid is present in various types of tissues, including synovial fluid, connective tissues and periarticular soft tissues. Under normal conditions, it is the main constituent of the extracellular matrix and the synovial fluid. It presents properties for joint lubrication, cartilage protection, joint pressure distribution, mechanics for shock absorption and maintenance of structural and functional viscoelastic characteristics in periarticular tissues. ${ }^{17,18}$

HA injections are used in viscosupplementation for the treatment of osteoarthritis. However, there is a recent interest in the use of HA in periarticular and soft tissue disorders, such as tendinopathies, ankle sprain, lateral epicondylitis, subacromial bursitis and partial ruptures of the rotator cuff, particularly in the younger athletic population. ${ }^{9}$ Some believe the medication can be identified by the body as biocompatible, similar to endogenous HA, making it active in the soft tissue healing process. ${ }^{10}$ It stimulates mitosis and immigration of epithelial cells and fibroblasts during the proliferative phase, contributes to the transformation of immature tenoblasts into tenocytes, and creates a better environment for cell growth with protein matrix accumulation and cell differentiation factors. ${ }^{1,10,19}$

There was no adverse event associated with the infiltrations. One of the most important limitations of this study is the lack of comparison with the control group; however, the small sample size is due to the selection patients with refractory periods to conservative treatment. It is a series of cases with a short follow-up period; however, the results of previous studies highlight the efficacy of the application up to 3 months of follow-up, without improvement after this period and with decline in results.

The Mayo Elbow Performance Score, as an analytical tool, was not specially developed for lateral epicondylitis. It is however a widely used index of performance for the evaluation of clinical outcomes for a variety of elbow-related conditions. ${ }^{20}$

\section{CONCLUSION}

Periarticular HA proved to be safe for patients resistant to treatments classically used in lateral epicondylitis within three months of follow-up. The individuals showed improvement in pain parameters (VAS), Mayo Elbow Performance Score (MEPS); however, regarding patient satisfaction, it offered $75 \%$ in symptom resolution, that is, a $25 \%$ failure rate.

AUTHORS' CONTRIBUTION: Each author contributed individually and significantly to the development of this article: GAS: writing, reviewing, intellectual concept of article and preparation of the entire research project; DHC: writing, reviewing and intellectual concept of the article; ST: writing, reviewing and intellectual concept of the article; PSB: article review; PHSL: writing, reviewing and intellectual concept of the article; BE: writing, reviewing and intellectual concept of the article.

\section{REFERENCES}

1. Tosun HB, Gumustas S, Agir I, Uludag A, Serbest S, Pepele D, Ertem K. Comparison of the effects of sodium hyaluronate-chondroitin sulphate and corticosteroid in the treatment of lateral epicondylitis: a prospective randomized trial. J Orthop Sci. 2015;20(5):837-43.

2. Boyer MI. Lateral tennis elbow: "Is there any science out there?". J Shoulder Elbow Surg. 1999;8(5):481-91.

3. Nirschl RP, Pettrone FA. Tennis elbow. The surgical treatment of lateral epicondylitis. J Bone Joint Surg Am. 1979;61(6):832-9

4. Nirschl RP. Elbow tendinosis/tennis elbow. Clin Sports Med. 1992;11(4):851-70.

5. Petrella RJ, Cogliano A, Decaria J, Mohamed N, Lee R. Management of tennis elbow with sodium hyaluronate periarticular injections. Sports Med Arthrosc Rehabil Ther Technol. 2010;2:4

6. Petrella MJ, Cogliano A, Petrella RJ. Original research: long-term efficacy and safety of periarticular hyaluronic acid in acute ankle sprain. Phys Sportsmed. 2009;37(1):64-70.

7. Khan IU, Awan AS, Khan AS, Marwat I, Meraj M. Efficacy of a single-injection sodium hyaluronate treatment in lateral epicondylitis. J Ayub Med Coll Abbottabad. 2018;30(1):85-9.

8. Frizziero A, Vittadini F, Barazzuol M, Gasparre G, Finott P, Meneghini A, et al. Extracorporeal shockwaves therapy versus hyaluronic acid injection for the treatment of painful non-calcific rotator cuff tendinopathies: preliminary results. J Sports Med Phys Fitness. 2017;57(9):1162-8.

9. Campbell RS, Dunn AJ. Radiological interventions for soft tissue injuries in sport. Br J Radiol. 2012;85(1016):1186-93.

10. Chen WY, Abatangelo G. Functions of hyaluronan in wound repair. Wound Repair Regen 1999;7(2):79-89.

11. Cusick MC, Bonnaig NS, Azar FM, Mauck BM, Smith RA, Throckmorton TW. Accuracy and reliability of the mayo elbow performance score. J Hand Surg Am. 2014;39(6):1146-50
12. Pienimäki TT, Tarvainen TK, Siira PT, Vanharanta H. Progressive strengthening and stretching exercises and ultrasound for chronic lateral epicondylitis. Physiother. 1996;82(9):522-30

13. Fogli M, Giordan N, Mazzoni G. Efficacy and safety of hyaluronic acid (500-730kDa) ultrasound-guided injections on painful tendinopathies: a prospective, open label, clinical study. Muscles Ligaments Tendons J. 2017;7(2):388-95.

14. Kumai T, Muneta T, Tsuchiya A, Shiraishi M, Ishizaki Y, Sugimoto K. The short-term effect after a single injection of high-molecular-weight hyaluronic acid in patients with enthesopathies (lateral epicondylitis, patellar tendinopathy, insertional Achilles tendinopathy, and plantar fasciitis): a preliminary study. J Orthop Sci. 2014;19(4):603-11.

15. Dong W, Goost H, Lin XB, Burger C, Paul C, Wang ZL. Injection therapies for lateral epicondylalgia: a systematic review and Bayesian network meta-analysis. Br J Sports Med. 2016;50(15):900-8.

16. Roque V, Agre M, Barroso J, Brito I. Managing knee ostheoarthritis: efficacy of hyaluronic acid injections. Acta Reumatol Port. 2013;38(3):154-61.

17. Kwon YW, Eisenberg G, Zuckerman JD. Sodium hyaluronate for the treatment of chronic shoulder pain associated with glenohumeral osteoarthritis: a multicenter, randomized, double-blind, placebo-controlled trial. J Shoulder Elbow Surg 2013;22(5):584-94

18. Abatangelo G, O'Regan M. Hyaluronan: biological role and function in articular joints. Eur J Rheumatol inflamm. 1995;15:9-16.

19. Petrella R, Cogliano A, Decruze A. SAT0602 Management of epicondylitis with single local injection of sodium hyaluronate. Ann Rheum Dis. 2017;76 Suppl 2:1002.

20. Cusick MC, Bonnaig NS, Azar FM, Mauck BM, Smith RA, Throckmorton TW. Accuracy and reliability of the Mayo Elbow Performance Score. J Hand Surg Am. 2014;39(6):1146-50. 